\title{
From Nature/Culture Dyad to Ecophobia: A Study of King Lear
}

\author{
Chin-Ching Lee
}

Department of English Language, Dayeh University, Taiwan

Copyright $(\mathcal{C} 2015$ by authors, all rights reserved. Authors agree that this article remains permanently open access under the terms of the Creative Commons Attribution License 4.0 International License

\begin{abstract}
In "Order of Man, Order of Nature," Montuschi discusses the smooth transition from Christian doctrine to the new science proposed by Francis Bacon. Bacon places his conception of knowledge and new science within the Christian tradition, proposing that human race can recover its divine right over nature. New science and knowledge advocate and enhance man's domination over nature. Fernandez-Armesto finds that the culture-nature dichotomy inscribed in Christianity and in the new science displays the notion that nature exists only to serve man's needs. He thus blames Renaissance humanism for its "collective narcissism of an entire species." This study intends to demonstrate that the history-laden value of cultural domination over nature is embraced in Shakespearean plays. Renaissance humanism, characterized by the arrogant notion that man has the upper hand over nature, is embraced in Shakespeare's King Lear, in which Lear's acquired humility and Gloucester's nihilistic recognition disclose ecophobia - the fear of the inconsistency and unpredictability of nature - and illustrate the desire to manipulate nature to decrease its threat. The hierarchy of the culture-nature dichotomy is further consolidated in the anxiety over and contempt for nature in this tragedy.
\end{abstract}

Keywords Culture, Nature, New Science, Ecophobia

\section{The Culture/Nature Dyad: A Tradition for Theological Purposes}

Etymologically speaking, the term "tradition" first appeared in English in the late fourteenth century from the Old French word tradicion, which means "delivery, surrender, a handing down." "Tradition" is not a static term, but a process which denotes "a very strong and often

1 This etymological definition comes from the Online Etymology Dictionary. predominant sense," and "tends to move towards age-old and towards ceremony, duty and respect" (Williams 1976, 319 emphasis mine). Raymond Williams[26,27] associates tradition with predominance and reverence, considering that tradition itself gives rise to the dialogue between the past and the future. In this sense, Roslyn M. Frank[12] lists several dyads, including culture/nature, man/woman, black/white, etc., to uncover the underlying hierarchical ordering within traditions, which function as "root metaphors' found in Western thought" (67). These dyads are indeed sets of asymmetric polarities; among them, the culture-nature dichotomy is to be discussed in this study.

The respective definitions of "nature" and "culture" should be explored first before this dyad is discussed. "Nature" is considered the most widely employed, most complex, and most ill-defined word in the English language. ${ }^{2}$ Aristotle[1] regards nature as the essence of a thing, "an inner principle of change and being" (Physics 2.1). On the other hand, nature also means anything that exists in the physical world; this idea gave rise to the study of natural sciences, such as physics, biology, etc. However, philosophical/theological perspectives relate nature to "the expression of the divine" and locate the idea of nature in the center of most religion (Borghini[8]). Once associated with religion, the concept of nature cannot be free from cultural influence and interaction.

The term "culture" is also highly contested, especially in anthropological studies. Edward B. Tylor[24] proposed that culture is learned and acquired instead of being a biological ingredient; culture, according to Tylor, "is that complex whole which includes knowledge, belief, arts, morals, law, customs, and any other capabilities and habits acquired by man as a member of society" (1). Culture is a whole way of life, characterized by the learned and shared codes of a group of people. However, a paradox occurs when the word "culture" is etymologically understood, given that it initially referred to "a cultivated field or piece of land" (Bate[7] 3),

2 Raymond Williams says that "Nature is the most complex word in the language" (1976, 219). Andrea Borghini points out that, in philosophy, the idea of nature is widely employed but ill defined. 
and later referred derivatively to "tillage, the working over the soil" (ibid). Its initial inseparability from land alludes to the phenomenon of man's labor and technology being used to enhance agricultural production.

The intricate interaction between nature and culture appears when they are respectively defined. Indeed, the metaphoric sets of dyads such as culture/nature, mind/body, man/woman, etc. often present asymmetric polarities, with one valued over the other. The polarity of culture/nature allows the former's domination of the latter, which is, to take Roslyn Frank's term, justified by "theological foundationalism, i.e., God's plan and a vertically oriented cosmology, then later simply as the Law of Nature" (69, emphasis mine). Social hierarchies are thus based on universalist concepts inherent in nature, in which this culture/nature asymmetry is justified and even encouraged both by Christianity and the schema of the Great Chain of Being. Both, according to Stephen Greenblatt[14], are meant to ensure a civil society, ${ }^{3}$ to deliver social order and hierarchy.

The antithetical concepts of nature and culture play a major role in Western thought, with a hierarchical order coded to make the physical entity - nature - manipulated, and then to justify culture as a privileged socioeconomic power. Christian thought, especially the ideas conveyed in Genesis, legitimizes cultural domination over nature by the ideal of the Garden of Eden. Indeed, The Book of Genesis recounts the story of creation, in which God creates the world by the end of the sixth day. God gives the following instruction to the humans created: "Be fruitful, and multiply, and replenish the earth and subdue it, and have dominion over the fish of the sea, and over the birds of the heavens, and over every living thing that moves upon the earth" (Gen. $1: 28$, emphasis mine). A hierarchy is thus established, with humans separated from the other creatures on earth; humanity's mastery is granted by God to deliver order and produce prosperity, "to cultivate it and to make it prosper" (Gen. 2:15). The Garden of Eden is portrayed as "the very incarnation of an orderly nature" (Montuschi[20] 5), in which human superiority over other creatures is promised, and human domination over nature is approved.

However, this harmonious relationship between man and nature is aborted when Adam and Eve are both chased out of Eden for their sin. The world outside of Eden is no longer a fertile site with easy satisfaction; instead, it is a hostile environment in which man must use all possible means to dominate nature in order to survive: "In the sweat of thy face shalt thou eat bread, till thou return unto the ground" (Gen. 2:12). Human survival requires harsh efforts and work to subdue nature through tools and man's diligence. Human sin leads to the collapse of Eden's prosperity, and also to "a state of constant competition with nature" (Montuschi 8). Indeed, as the Great Chain of Being is considered the most prevalent ideology during the

3 Greenblatt claims that "the primary function [of religion] is not salvation but the achievement of civic discipline" (20).
Renaissance era, God is presented as the Authority, after which come angels, humans, and non-humans. Nature (in the form of non-humans) is relegated, in this view, to being in a position of servitude to man. This strict hierarchy delivers social stability and guarantees order. Lynn White[25] therefore asserts that Christianity is "the most anthropocentric religion the world has seen" (9), one which will continue to cause a "worsening ecologic crisis until we reject the Christian axiom that nature has no reason for existence save to serve man" (16). Likewise, George Lakoff[17] and Mark Turner[17] consider the Great Chain of Being "a political issue," defining it as "a chain of subjugation" rooted in the asymmetrical interrelationship between man and nature (213). Nature is therefore utilized to legitimize the existing social order; the universe appears harmonious, operating under God and ruled by humans.

\section{Baconian New Science/Natural Knowledge in Service of Culture-nature Dichotomy}

L.J. Jordanova[16] proposes that culture's power lies in "its ability to manipulate nature and shape its surroundings in a way that demonstrates its boundless influence" (46). Cicero (106BC-43BC) addressed such cultural manipulation of nature in the century before the advent of Christendom. In De Natura Deorum, Cicero claims that "by means of our hands we try to create as it were a second nature within the world of Nature" (qtd. Montuschi 12, emphasis mine). Cicero's claim that man can create a second nature within Nature is further developed by Francis Bacon[2-6] (1561-1626). Said to be the creator of empiricism and a key philosophical influence ahead of the Industrial Age, Bacon proposes that all scientific works should be conducted for charitable purposes to alleviate human misery and improve the human estate.

In The Advancement of Learning (1605), Bacon claims that the pure knowledge of Nature and universality is for "the glory and the good of humanity" (VI. 6). However, the knowledge leading to man's fall is different than the pure kind; it is "the proud knowledge of good and evil, with an intent in man to give law unto himself, and to depend no more upon God's commandments" (I.3); in other words, it will lead man to "make a total defection from God and to depend wholly upon himself" (VI. 6). Bacon therefore thinks there are two books that all men should study: the first is Scripture in order to know the will of God, and the second is the book of Nature in order to know the power of God - "the latter whereof is a key to the former" (71). As for knowledge, Bacon considers that "a little or superficial knowledge ... may incline the mind of men to atheism, but a further proceeding therein doth bring the mind back again to religion" (I.3). Bacon also proposes to "seek the dignity of knowledge in the archetype or first platform ... in the attributes and acts of God" (VI, 1); the advancement of 
learning and knowledge will not lead to man's rebellion against God, but will instead reproduce the original dominion of man over nature to glorify the Almighty, as promised and justified in Genesis. Work is the only means to make nature subordinate to man's needs, which are not achieved by the naked hand or by the unaided intellect, but by tools and help. ${ }^{4}$ Obviously, knowledge and Bacon's book Novum Organum (the title of which is Latin for "the new instrument") are within the Christian tradition, which features a consistent ideology of mastery over nature, parallel with the Christian hierarchy of man over other creatures, and culture over nature.

In Novum Organum, Book I, Bacon proposes that "Knowledge and human power are synonymous," and, furthermore, that "nature is only subdued by submission" (Novum III). Montuschi thus claims that the Baconian ideal of the new instrument is to "learn from nature ... how to use it in order wholly to dominate it" (15). For Bacon, the Book of Nature is God's work; the natural philosophy is "the surest remedy against superstition, and the most approved support of faith ... a most faithful attendant, for ... exhibit[ing] the will and ... the power of God" (Novum LXXXIX). Knowledge and learning are regarded as being in the service of the Christian God as the Primal Authority, and humanity is viewed as the dominant actor in the mundane world. Nature functions as an instrument through which to reach cultural domination in the service of Christianity.

In this sense, Bacon blames humans for their ignorance of the natural world, suggesting that observation and rationality be combined in order to remedy man's inadequate understanding of the natural world. However, as R.W. Serjeantson[22] points out in his discussion of Bacon's New Atlantis, applying the term "science" to discuss Bacon's work would be anachronistic because "science" is a creation of the nineteenth century, not the seventeenth century (84). As such, Serjeantson suggests adopting "natural knowledge" rather than "science," as the former bears a closer resemblance to the Renaissance Latin term "scientia naturalis" (84). The anachronistic term "science" may confound the Renaissance's focus on "the secrets of nature," and on "practical knowledge - on making and doing as the best means of understanding the world" (Serjeantson 86). The book of Nature was studied in the Renaissance, in which "natural magic ... was concerned exclusively with natural, not with supernatural effects" (Serjeantson 89). Therefore, Salomon's House in New Atlantis is dedicated to "the study of the Works and Creatures of God" - nature; by studying the book of Nature, the inhabitants of New Atlantis are also honoring their Creator, Christian God. Natural knowledge focuses on the understanding of nature, which converts the people of

4 "The unassisted hand and the understanding left to itself possess but little power. Effects are produced by the means of instruments and helps, which the understanding requires no less than the hand; and as instruments either promote or regulate the motion of the hand, so those that are applied to the mind prompt or protect the understanding" (Novum Organon Book 1, II).
Bensalem in New Atlantis to Christianity and enables them to thus become "consummate natural theologians" (Serjeantson 92).

Bacon's natural knowledge in New Atlantis (1623) is meant to generate pragmatic utilities by manipulating nature. To Bacon, learning and studies should be pragmatic, as Montuschi considers "[p]ractical knowledge, applied science, and useful action ... to be ... the emergent features of Bacon's ideal of a scientia operative" (14). The book discusses a fictional island called Bensalem located in the Pacific Ocean, on which freedom of religion and racial equity exist. On the other hand, in this utopian new world, Nature's chief function is to serve humans and satisfy their needs. People in Bensalem associate knowledge with "the enlarging of the bounds of human empire, ... [and] the effecting of all things possible" (1691). The ambition of Baconian knowledge is to dominate nature; therefore, fruit trees and flowers in Bensalem are made "by art greater much than their nature ... greater and sweeter, and of differing taste, smell, color, and figure, from their nature" (1693). Such Baconian positivism and empiricism deny the likelihood of humanity's transcendental interaction with nature. ${ }^{5}$ Donald Worster[28] therefore argues that the anthropocentric tradition proposed by Bacon has "stripped from nature all spiritual qualities," and could better be described "as the "imperial view of nature, for ... it has made the domination of the earth - often promoted in the name of a purely secular welfare - one of modern man's most important ends" (29). In addition, Worster claims that Bacon is an exponent of the aforementioned imperial ideology, because he promises a man-made paradise rendered fertile by humans, in which man would reclaim authority over nature. In short, the Baconian ideology invites the advancement of natural knowledge to reclaim the control over nature granted in Christianity, and then to renovate the human estate.

In the preface to The Great Instauration, Bacon proposes that "the true ends of knowledge ... [are] for the benefit and use of life," which is not a sin because "... of charity there can be no excess." Cultural predominance over nature is further justified by man's survival, by civil social order, and by man's desire for a better life. In this sense, the power of culture lies in its capability to manipulate and shape nature, so as to satisfy human needs and to ensure societal order. Baconian positivism incorporates observation and human reason into the advancement of learning and knowledge. Through observation, man can free himself from previous contemplative models that inhibit progression and advancement. Bacon proposes to "seek the dignity of knowledge in its original" (Advancement 67) - nature which is considered "a storehouse for the glory of the Creator and the endowment of human life" (Advancement

5 In Novum Organum, Bacon points out "Idols of the Tribe" (Idola Tribus), claiming that "all perceptions of sense and mind are built to the scale of man and not the universe" (aph. 4). Nature can no longer be personified with intrinsic values; instead, nature is reified with instrumental values. 
66). Man, apart from nature rather than a part of nature, takes nature as an object to study, to dominate, and to manipulate for human benefits. 6 For Bacon, the real value of thought lies in its practical uses; this anticipates the new science and forms of knowledge as "a means for domination ... in the sense of supporting a science of coercive action" (Montuschi 16, emphasis mine). Learning and knowledge enable the cultural coercion of nature; such "ecophobia" - "an irrational and groundless fear or hatred of the natural world" which justifies man's need to dominate nature (Estok[10] 4) - is dramatized in Shakespeare's[23] King Lear.

\section{Ecophobia in King Lear}

The hierarchical nature-culture duality leads to the perspective of privileging culture and marching toward advancement; anthropocentric philosophy is thus taken for granted. The notion of culture standing in sharp opposition to nature defines civilization as "a [man's] relationship to the natural environment, recrafted, by the civilizing impulse, to meet human demands" (Fernandez-Armesto 14, emphasis mine). World history contains human beings' relationships with each other and with the surrounding environment. This definition denies mutual exclusiveness as characteristic of the culture-nature dichotomy, and justifies man's dominion over nature, which is deemed to be a god-given right in western culture. Simon C. Estok also considers human nature "a history of controlling the natural environment" (6).

In "On Gardens," Bacon claims that "God Almighty first planted a garden. And, indeed, it is the purest of human pleasures"; through the image of the Garden, Bacon claims that natural bounties are expected and granted to humans. At the center of the world, man's domination of the world is justified. In addition, such an anthropocentric ideology proposes that only human beings bear intrinsic values; all other creatures and the surroundings display instrumental values only. Felipe Fernandez-Armesto thus finds that the word "civilization" usually denotes "a process of collective self-differentiation from a world characterized $\ldots$ as 'barbaric' or 'savage' or 'primitive"' (13); culture moves toward "the renunciation of nature" (ibid). Such "human arrogance" coincides with the hierarchical orders in the Great Chain of Being. This cultural notion usually denotes the intention 'to 'denature' humanity: to fillet the savage out of themselves, to domesticate the wild man within by elaborate clothes and manners" (Fernandez-Armesto 15). The idea of savagery refers to "the absence of culture and civilization" (Estok 24); it also implies "the horror of an invasive and hostile nature" (ibid). The cultural control of

6 In The Great Instauration (1620), Bacon ends the six parts of his plan with a prayer to God, who "breathe[s] into the face of man the intellectual light as the crown and consummation thereof, [to] guard and protect this work , which coming from thy goodness returnth to thy glory...". nature and the general contempt for savagery generate the idea of "ecophobia" - a term that implies "the primary way that humanity responds to nature" (Estok 2).

With culture redefined as interaction with the environment/nature, and progress denied as an unalienated cultural effect, the contemporary interrogation of the culture-nature dyad hopefully affords a fresh perspective. In the Renaissance Age, Christian faith embraced the hierarchical orders. Baconian ideology, as displayed in The Advancement of Learning, Novum Organum, and New Atlantis, consolidates human manipulation of and dominion over nature. Fernandez-Armesto thus sarcastically blames Renaissance humanism for its "collective narcissism of an entire species," which upgrades humans as "God's best shot, or, in secular language, the climax of evolution" (545). Such a "delusive form of self-flattery" (545), to take Fernandez-Armesto's term, can be found in the Renaissance concept of the Great Chain of Being, and in Bacon's proposal for learning and knowledge. The contempt for nature and arrogant wish for dominion over nature are also dramatized in King Lear by Shakespeare.

Of all Shakespeare's tragedies, only King Lear is set in England, distant from the author himself only in temporal, rather than spatial, terms. In the tragedy, human dominion over land is displayed when Lear divides Britain into three parts. Lear's love test of his three daughters demonstrates his preference for flattering tricks over sincere love. He associates the division of the state land with the amount of filial love shown by his daughters, wishing to renounce his political title and its obligations. Lear thus asks: "Which of you shall we say doth love us most?" (I.i.50, emphasis mine). Here "us" may comprise the land, power, and kingship, as well as Lear the father. Goneril's and Regan's sweet flattering helps them get parts of the territory, which Lear delineates as "Of all these bounds, even from this line to this, / With shadowy forests and with champains rich'd, / With Plenteous rivers and wide-skirted meads" (I.i.62-4). The land bounties are manipulated and distributed for political/personal purposes. However, when nature is under the charge of culture, natural unpredictability and subversiveness occur, leading to disarray in family relationships and in the state rather than to progress and advancement.

The division of the state land displays an anthropocentric attitude toward the surrounding natural environment. In addition, that Lear delegates his Divine Right to his daughters (Goneril and Regan) leads to social anarchies such as the rumor between Albany and Cornwall, the murder of Cornwall by his servant, the animosity between Regan and Goneril, and the invasion of the French armies. When discussing Shakespearean ecophobia, Estok assumes that, as soon as Lear loses control over the land, he is dispossessed and displaced, "victimized by the weather, unhoused, and alienated" (21). On the other hand, King Lear's disowning of Cordelia dissolves his paternal responsibility and thus interrupts the parental order. Disorder appears on account of man's willful manipulation 
of the land/nature to satisfy individuals' wishes; anthropocentric control over nature that guarantees advancement is challenged in the face of natural unpredictability.

King Lear's irrational decision results in chaos. Estok assumes that in King Lear, utilitarian views toward nature occur, "represent[ing] an object space that must be controlled, without which it is a dangerous space of chaotic nothingness" (26). Lear foregoes the utilitarian perspective of the land, thus trapping himself in the coming chaos metaphorically displayed in the storm. Lear is one character associated with the utilitarian usage of nature/land. On the other hand, Edmund, an illegitimate bastard who falls outside the ideologically sanctioned space of the home, outside of the marriage system, and also outside of the privileges of property, attempts to wreck the cultural order. He thirsts for legitimacy, recognition, wealth and land, which are all denied due to the primogeniture system. Cultural order, here referring to the primogeniture system, is thus denied by Edmund in response. After Gloucester mistakes Edmund to be a "loyal and natural boy," this "a-cultural" notion is furthered still more by Edmund's petition to nature - "Thou, Nature, art my goddess, to thy law / My services are bound" (I.ii.1-2). Edmund's invocation to Nature is intended to renounce both religion and the Laws of human society. By showing his loyalty to nature, Edmund embraces the disorder, chaos, and horror that nature displays. Nature/land here is appropriated in his invocation as an instrument with which he can fight for his own wishes and profit, and as an aid in endorsing his social status and power.

Indeed, there is another important natural element that occurs in the tragedy: a violent storm, which associates nature with "a hostile opponent to be feared and, with any luck, controlled" (Estok 6). The storm on the heath connotes man's fear and loathing of nature characterized by unpredictability. Ecophobic anxiety is outwardly presented in the form of the storm, and inwardly delivered in the form of madness. Specifically speaking, the storm, mirroring Lear's inner turmoil and mounting madness, is a physical and natural reflection of Lear's internal upset and confusion. Therefore, when Kent asks "Who's there, besides foul weather?" a gentleman replies by identifying Lear as "One minded like the weather, most unquietly" (III.i.1-2). In the meantime, Lear regards the storm as his ungrateful daughters' ally: "But yet I call you servile ministers. / That have with two pernicious daughters join'd / Your high engender'd battles 'gainst a head / So old and white as this. O! O! 'tis foul!" (III.ii.21-25). The storm reminds Lear of the filial ingratitude of his two sinister daughters, whom Lear intends to fight against. Thereby, Lear is found to wage war against nature regardless of his frailties: "Contending with the fretful elements; / Bids the wind blow the earth into the sea, / Or swell the curled waters 'bove the main, / That things might change or cease; tears his white hair, / Which the impetuous blasts, with eyeless rage, / Catch in their fury, and make nothing of; / Strives in his little world of man to out-storm / The to-and-fro-conflicting wind and rain" (III.i.4-11). Lear's inner struggles are amplified when he fights against nature, with a wish to grasp any tiny possibility of controlling within and with-out. $\mathrm{He}$ is desperate for control over exterior nature, even in such a state of disarray.

Later on, on the heath, Lear again launches a famous speech to the storm, which not only echoes his inner turmoil, but inadvertently displays man's insignificance in the face of capricious nature: "Blow, winds, and crack your cheeks! Rage! Blow! / You cataracts and hurricanes, spout / Til you have drench'd our steeples, drown'd the cocks! / You sulph'rous and thought-executing fires, / Vaunt-couriers of oak-cleaving thunderbolts, / Singe my white head! And thou, all-shaking thunder, / Strike flat the thick rotundity o'th' world! / Crack Nature's moulds, all germens spill at once / That makes ingrateful man!" (III.ii.1-9, emphasis mine). The awesome power of nature awakens Lear to mortal frailty, and triggers Lear's humility and sympathy toward the people around him. When Lear wanders into the wilderness, he can see through outward appearances into human fear, frailties, and falsehood. The storm, which represents the apocalyptic power of nature, forces Lear to repent for his previous hubris, to sympathize with the people around him, and to acknowledge that cultural pretensions endorse falsity and snobbery. On the other hand, the storm also wields a menacing power against the displaced Lear. The storm therefore needs to die away to symbolically retrieve the state of placidity, and to endorse cultural dominion over nature.

In King Lear, when land/nature is abused for individual profits, disorder emerges due to nature's unpredictability. The dyad of clothing and nakedness also displays the ecophobic anxiety over nature's subversiveness in the form of monstrosity. Clothes are regarded as a symbol of man's ascendency over animals. When Goneril decreases Lear's attendants, Lear says: "Allow not nature more than nature needs, / Man's life's as cheap as beast's" (II.iv.269-70). Lear takes power and attendants as cultural signifiers of humanity's superiority over animals. However, in storm and madness, Lear is found "singing aloud; / Crowned with rank fumiter and furrow-weeds" (IV.iv. 2-3). Wearing a crown of wild flowers, Lear is now associated with nature rather than the world of the court, stuck in madness and plunged into nothingness. Lear's losing control of the land deprives him of clothes and manners, turning him into a wild mad man on the stormy heath. The fear of nature's devastating power reinforces the anthropocentric wishes to manipulate nature. Human anxiety over nature's unpredictability also leads to the nihilistic idea in Lear's ramblings - "Reason in madness" (IV.iv.173), as Edgar remarks in an aside - that everyone is the same, that beneath clothing each person is "a poor, bare, forked animal" (III.iv.99-100). The loss of the land "de-cultures" Lear, alienating him from royal comfort and material advancement. Lear is a human equated with animals. Such animal images dissociate humanity from culture, downgrading humanity to the a-cultural norm. Thus, 
Lear is considered by the Fool to be like a hedge sparrow whose head has been bit off by its young. Goneril and Regan are described as predatory animals such as the "detested kite" and the "gilded serpent," as "tigers, not daughters"; brutality rather than humanity is characteristic of the two daughters. Animal images are also adopted to invalidate the justice of providence when Lear, at the end of the play, cradles Cordelia's dead body and asks "Why should a dog, a horse, a rat have life / And thou no breath at all" (V.iii.305-6). The devastating power of nature in the form of monstrosity is scary and incomprehensible.

In addition, just like a storm can devastate all, and nakedness implies nothingness, a key word that occurs in the tragedy many times conveys a similar connotation "nothing." However, when nature presents its subversive potential in the storm, this "nothing" cannot be considered nothing only; on the contrary, it means a great deal more than nothing. Therefore, when Edgar talks about himself, saying "Edgar I nothing am" (II.iii.21), he is by the end more than nothing because order is retrieved by his judgment and predominance. Here "nothing" actually means a great deal more than nothing, and nature's unpredictability generates instability within and outside of the text.

However, when Lear is deprived and displaced, "nothing" again coincides with nature's devastation. Indeed, in King Lear, order lapses into disarray and ultimately into nothing for Lear. Indeed, the idea of "nothingness" first delivers devastative potentials: after Lear's loss of identity (kingship) comes Lear's reduction to nothingness - a situation which is sarcastically described by the Fool: "Now thou art an $\mathrm{O}$ without a figure / I am better than thou art now; I am a fool, / thou art nothing." (I.iv.211-3). The Fool's words testify to Lear's being dispossessed of his kingship and his identity, placing him outside the cultural order and plunging him into the natural devastation. With dispossession as a foregone conclusion of nature's subversion of culture, ecophobic anxiety is once again triggered to guarantee man's privileged status over nature.

When order is restored by the death of Goneril and Regan, and by the duel between Edgar and Edmund in which the former defeats the latter, monstrosity is eradicated to restore humanity/order, but the order restored is no longer the same as it once was. Though Edgar insists that "the gods are just" (V.iii.169), uncertainties occur when the good dies along with the wicked - all the main characters die except Edgar and Albany. In addition, when Gloucester wanders on the heath after being blinded, he says: "As flies to wanton boys, are we to the gods; / They kill us for their sport." (IV.i.37-8). This nihilistic anxiety acts as a potentially subversive power to question the cultural order of omnipotent God Almighty, and to reveal the malicious natural order as well; the former is justified by the setting of a godless pre-Christian England, while the latter substantiates the need to drive away nature's unpredictability. Once cultural dominion over nature fails, man's groundless fear and hatred of the natural world ecophobia - appear. Such anxiety leads to humanity's desire for comprehensive dominion of nature in case such disorder should occur.

The notion, in theological and social belief, that nature is something to be dominated lest it run riot and out of control is embraced in King Lear. Nature is, at first, being manipulated when the territory of the state is divided, but then shows itself to be beyond the control of humans, as the merciless storm attacks those on the heath. This arrangement leads to Lear's final recognition that his lifelong duties of being a king, a father, and a man, are denied when he finds himself none of these. In King Lear, cultural order is believed to make possible the operation and enhancement of the state and the individuals. However, when nature surmounts men's/Lear's rational control, its subversiveness drives the characters into madness, blindness, disentitlement, and, eventually, displacement.

\section{Conclusion}

That fact that nature is mixed with man's labor would question the separation of natural history from social advancement (Williams 1980, 76). However, cultural encroachment into nature has always been considered a God-given right. In addition, the notions upheld in Bacon's essays coincide with the dominant ideology of anthropocentric notions; nature delivers only instrumental values to offer service to humans. Likewise, on the heath in King Lear, as in Bacon's statement regarding learning and knowledge, culture and nature intermingle, with culture being privileged over nature, but at the same time, man faces the potential inconsistency of nature. Once the cultural privileges give way to natural devastation, disorder occurs; therefore, man's motivation to domesticate nature guarantees the likely coercion of nature's unpredictability. Ecophobia is thus justified.

The Advancement of Learning by Bacon was published in 1605. Bacon proposes the study of nature through observation; in nature there is "the dignity of knowledge in the archetype or first platform, ... in the attributes and acts of God" (Advancement VI, 1). Bacon continues elaborating on the importance of natural knowledge in The Novum Organum (1620), and sketches a utopian ideal in New Atlantis (1624). The Renaissance ideology of the Great Chain of Being is embraced, with God as the primal Almighty in heaven, and humanity as the predominant power on earth. In King Lear, Shakespeare dramatizes humanity's need to achieve rational supremacy over nature. Lear's willful manipulation of the land leads to a crisis of national sovereignty, and to the death of the innocent and good. The anxiety in the face of nature's unpredictability, a condition referred to by Estok in his coinage "ecophobia," demonstrates man's fear of nature's potential sinister power. On the heath, Lear appears powerless, wrecked by the pitiless storm and scorned for being nothing but a man with a crown of wild flowers. The heath is a wild place, in which cultural elements disappear, so that non humans are no 
longer mere instruments for humans. This stormy heath delivers natural subversiveness instead of cultural obedience, plunging Lear into mental disorder and nothingness. The Renaissance, an era of flourishing knowledge and progress in various areas of human endeavor, guarantees humanity's potentials in terms of natural knowledge. The Baconian focus on instrumental values and human manipulation, and the Shakespearean privilege of cultural advancement over natural nothingness, both invite discussion of the culture-nature dyad - a dichotomy long embraced, but questioned now.

\section{REFERENCES}

[1] Aristotle, Physics, Books I-II, trans. W. Charlton, Clarendon Press, Oxford, 1970.

[2] F. Bacon, Preface to the Instauratio Magna, 2013, Online available from http://www.bartleby.com/39/20.html

[3] F. Bacon, The Advancement of Learning, Ed. J. Devey, P.F. Collier, New York, 1902.

[4] F. Bacon, The New Organon, Ed. J. Devey, P.F. Collier, New York, 1902.

[5] F. Bacon, The Great Instauration, 2013, Online available from http://www.constitution.org/bacon/instauration.htm, Sep 12, 2014.

[6] F. Bacon, The New Atlantis, The Norton Anthology of English English, 5th Edition, Eds. M. H. Abrams, etc., W. W. Norton \&Company, New York, 1986.

[7] J. Bate, The Song of the Earth, Harvard UP, Cambridge, 2000.

[8] A. Borghini, The Idea of Nature: Philosophical Perspectives, 2013, Online available from http://philosophy.about.com/od/Philosophical-Theories-Idea s/a/The-Idea-Of-Nature.htm, Sep 15, 2014.

[9] L. Buell, The Future of Environmental Criticism: Environmental Crisis and Literary Imagination, Blackwell P., Malden, 2005.

[10] S. C. Estok, Ecocriticism and Shakespeare: Reading Ecophobia, Palgrave MacMillan, New York, 2011.

[11] F. Fernandezz-Armesto, Civilizations: Culture, Ambition, and the Transformation of Nature, Free Press, New York, 2001.

[12] R. M. Frank, Shifting Identities: The Metaphorics of Nature-Culture Dualism in Western and Basque Models of Self, Metaphorik.de, 4, 66-92, 2003.
[13] T. Gifford, The Social Construction of Nature, ISLE, 3.2, 27-35, 2012.

[14] S. Greenblatt, Invisible Bullets: Renaissance Authority and Its Subversion, Henry IV and Henry V. Political Shakespeare: New Essays in Cultural Materialism, Ed. J. Dollimore and A. Sinfield, Cornell UP, Ithaca, 18-47, 1985.

[15] M. Hebron, Key Concepts in Renaissance Literature, Palgrave MacMillan, New York, 2008.

[16] L. J. Jordanova, Natural facts: a historical perspective on science and sexuality. Nature, Culture and Gender. Ed. C. MacCormack and M. Strathern, Cambridge UP, New York, 42-69, 1980.

[17] G. Lakoff and M. Turner, The Great Chain of Being. More than Cool Reason: A Field Guide to Poetic Metaphor, The University of Chicago Press, Chicago, 160-213, 1989.

[18] C. Lévi-Strauss, The Savage Mind, The University of Chicago Press, Chicago, 1966.

[19] L. Marx, Shakespeare's American Fable, The Machine in the Garden: Technology and the Pastoral Ideal in America, Oxford UP, Oxford, 34-72, 1964.

[20] E. Montuschi, Order of man, order of nature: Francis Bacon's idea of a "dominion" over nature, Order: God's, Man's and Nature's, The British Library, London, 1-25, 2013.

[21] Online Etymology Dictionary, 2013, Online available from $\mathrm{http}: / / \mathrm{www}$.etymonline.com/index.php?allowed in frame $=0$ $\&$ search $=$ traditio \&searchmode $=$ none

[22] R. W. Serjeantson, Natural Knowledge in the New Atlantis. Francis Bacon's "New Atlantis", Ed. B. Price, Manchester UP, Manchester, 82-105, 2002.

[23] W. Shakespeare, The Tempest. Ed. F. Kermode, Methuen, New York, 1980.

[24] E. B. Tylor, Primitive Culture, J.P. Putnam's Sons, New York, 1920.

[25] L. White, The Historical Roots of Our Ecological Crisis, The Ecocriticism Reader: Landmarks in Literary Ecology, Ed. C. Glotfelty and H. Fromm, George UP, Athens, 3-14, 1996.

[26] R. Williams, Keywords: A Vocabulary of Culture and Society, Fontana Press, London, 1976.

[27] R. Williams, Ideas of Nature. Problems in Materialism and Culture, Verso, London, 67-85, 1980.

[28] D. Worster, The Empire of Reason. Nature's Economy: A History of Ecological Ideas, Cambridge UP, Cambridge, 26-55, 1994. 